\title{
PENINGKATAN HASIL BELAJAR PESERTA DIDIK DENGAN MENGGUNAKAN MEDIA AUDIO VISUAL PADA MATA PELAJARAN IPA DI KELAS IIISDN 50 BULU'DATU PALOPO
}

\author{
Arlianti \\ Institut Agama Islam Negeri Palopo \\ AJl. Agatis Balandai Kota Palopo 91914 \\ E-mail: arlianti29@gmail.com
}

\begin{abstract}
The purpose of this study was to determine the use of audio-visual media that can improve science learning outcomes in the third grade of SD 50 Bulu 'Datu. This research is classroom action research (PTK) with qualitative and quantitative research types consisting of two cycles each cycle 3 meetings, data collection techniques carried out by observing, testing, documentation with the stages of planning, implementation, observation, reflection. The results showed that: by using audio-visual media in science learning the learning outcomes of students increased, it can be seen in the data obtained which showed that the average value in class III in the first cycle reached 73 but there were still several students who are still lacking and the researchers proceed to cycle II, the learning outcomes of students increase with the results of the average score reaching 95 based on minimum completeness criteria (KKM) in science subjects have achieved results and researchers end this research until the second cycle.
\end{abstract}

Keywords: Learning Outcomes, Learners, Audio Visual Media

\begin{abstract}
Abstrak
Tujuan penelitian ini adalah untuk mengetahui penggunaan media audio visual yang dapat meningkatkan hasil belajar IPA di kelas III SDN 50 Bulu' Datu. Penelitian ini merupakan penelitian tindakan kelas (PTK) dengan jenis penelitian kualitatif dan kuantitif yang terdiri dari dua siklus masing-masing siklus 3 kali pertemuan. Teknik pengumpulan data dilakukan dengan cara observasi, tes, dokumentasi dengan tahap perencanaan, pelaksanaan, observasi, dan refleksi. Hasil penelitian menunjukkan bahwa dengan menggunakan media audio visual dalam pembelajaran IPA hasil belajar peserta didik jadi meningkat, hal tersebut dapat dilihat pada data yang diperoleh yang menunjukkan bahwa nilai rata-rata di kelas III pada siklus I mencapai 73 namun dalam pembelajaran ini masih ada beberapa siswa yang masih kurang dan peneliti melanjutkan ke siklus II maka hasil belajar peserta didiklebih meningkat dengan hasil nilai ratarata mencapai 95 berdasarkan kriterian ketuntasan minimal (KKM) pada mata pelajaran IPA sudah mencapai hasil dan peneliti mengakhiri penelitiann ini sampai siklus II. .
\end{abstract}

Kata Kunci,: Hasil Belajar, Peserta Didik, Media Audio Visual.

\section{PENDAHULUAN}

Pembelajaran IPA merupakan pembelajaran yang terdiri atas proses, produk dan sikap sebagai acuan untuk mengetahui kompetensi siswa dalam mencapai hasil belajar yang baik (Amir, 2013; Suastra, 2009). Pembelajaran IPA lebih menekankan pada pengalaman langsung kepada peserta didik untuk memperoleh pemahaman yang cukup mendalam tentang alam sekitar 


\section{6 | Arlianti}

sehingga para peserta didik dapat menerapkannya dalam kehidupan seharihari (Widodo et al, 2012). Sains adalah usaha manusia dalam memahami alam semesta melalui observasi yang tepat pada sasaran, dan menggunakan prosedur yang dijelaskan dengan penalaran sehingga mendapatkan suatu kesimpulan. Perkembangan ilmu pengetahuan termasuk sains turut berperan serta dalam mempererat hubungan antar bangsa di ma sa globalisasi saat ini (Rustan, 2001). Oleh karena itu, guru diharapkan dapat mengerti hakikat pembelajaran IPA agar tidak kesulitan dalam mendesain dan melaksanakan pembelajaran. Peserta didik yang melakukan pembelajaran juga tidak mendapat kesulitan dalam memahami konsep sains (Ahmad Susanto. 2015:167), sehingga apa yang telah diinginkan bisa tercapai dengan baik.

Kedudukan IPA sebagai proses yaitu: 1) IPA sebagai proses mengandung pengertian cara berfikir dan bertindak untuk menghadapi atau merespon masalah-masalah yang ada di lingkungan. Jadi, IPA sebagai pro ses menyangkut proses atau cara kerja untuk memperoleh hasil (produk) inilah yang kemudian dikenal sebagai proses ilmiah. 2) IPA sebagai produk sekumpulan hasil kegiatan empirik dan kegiatan analitik yang dilakukan oleh para ilmuwan selama berabad-abad. 3) IPA sebagai sikap ilmiah adalah sikap tertentu yang diambil dan dikembangkan oleh ilmuwan untuk mencapai hasil yang diharapkan (Hisbullah \& Nurhayati Selvi. 2018: 5-12).

Berdasarkan observasi awal yang dilakukan peneliti di SDN 50 Bulu' Datu menujukan bahwa hasil belajar IPA peserta didik masih rendah hal ini dapat dilihat dari banyaknya peserta didik bercerita saat guru menjela skan materi ada juga yang terlihat mengantuk saat proses pembelajaran berlangsung. Hal demikian memicu rendahnya hasil belajar peserta didik karena kurangnya media pembelajaran yang menarik. Peneliti dalam hal ini menggunakan media audio visual untuk meningkatkan hasil belajar peserta didik pada mata pelajaran IPA. Dalam pembelajaran IPA terdapat beberapa proses yang dapat diaplikasikan pada siswa yaitu mengamati, pengukuran, interprestasi atau mentafsirkan, klasifikasi atau pengelompokkan, prediksi dan komunikasi (Sujana, 2014: 44).

Proses belajar itu terjadi karena adanya interaksi antara seseorang dengan lingkungannya. Oleh karena itu, belajar dapat terjadi kapan saja dan di mana saja. Salah satu tanda bahwa seseorang itu telah belajar adalah dengan adanya perubahan tingkah laku pada diri orang itu yang mungkin disebabkan oleh terjadinya perubahan pada tingkat pengetahuan, keterampilan, atau sikapnya. Apabila proses belajar itu diselenggarakan secara formal di sekolahsekolah, tidak lain ini dimaksudkan untuk mengarahkan perubahan pada diri peserta didik secara terencana, baik dalam aspek pengetahuan, keterampilan, maupun sikap. Pengaplikasian kurikulum 2013 diharapkan mampu 
meningkatkan daya saing siswa menghadapi isu global dimana dimana selain pengetahuan dan keterampilan, karakter siswa juga dikembangkan secara vertikal dan horizontal antar mata pelajaran (Rustan, Hanifah, \& Kanro, 2018).

Interaksi yang terjadi selama proses belajar dipengaruhi oleh lingkungannya, antara lain terdiri yaitu murid, guru, petugas perpustakaan, kepala sekolah, bahan atau materi pembelajaran (buku, modul, selebaran, majalah, rekaman video atau audio, dan yang sejenisnya), dan berbagai sumber belajar dan fasilitas (preyektor overhead, video, televisi, komputer, perpustakaan, laboratoriun, pusat sumber belajar, dan lain-lain (Azhar Arsyad.2014: 1). Adapun yang menjadi masalah dalam pembelajaran IPA yaitu ditandai dengan kurang aktifnya peserta didik dalam menerima pelajaran, dikarenakan cara penyampaian materi kurang menarik perhatian paserta didik. Adapun solusi yang dapat dilakukan adalah dengan menggunakan media audio visual yang dapat membuat peserta didik lebih fokus dalam menerima pelajaran.

Menurut (Rusman 2013 :169) Media adalah pengantar pesan dari pengirim ke penerima pesan, dengan demikian media merupakan wahana penyalur informasi belajar atau penyalur pesan. Media adalah saluran informasi yang menghubungkan antara sumber informasi dan penerima (HM. Musfiqon, 2012 : 26). Media menurut batasanya perangkat lunak yang berisiskan pesan (informasi) pendidikan yang lazimnya disajikan dengan menggunakan peralatan. Ditinjau dari kesekian pengadaannya, media dikelompokkan dalam dua jenis yaitu media jadi merupakan komoditi perdagangan dan terdapat di pasaran luas dalam keadaan siap pakai (medi by untilization), dan media dirancangan karena perlu dirancang dan dipersiapakan secara khusus untuk maksud dan tujuan pmbelajaran tertentu (Sadiman. 2009:83).

Media pembelajaran adalah setiap orang, bahan, alat, atau peristiwa yang dapat menciptakan kondisi yang memungkinkan pembelajaran untuk menerima pengetahuan, keterampilan dan sikap.dengan pengertian itu, maka guru atau dosen, buku ajar, serta lingkungan adalah media (Sri Anita. 2012:6). Istilah media audio visual terdiri dari tiga kata yaitu media,audio dan visual, adapun arti dari ketiga kata tersebut adalah; kata media berasal dari bahasa latin dan merupakan bentuk jamak dari kata "medium" yang secara harfiah berarti perantara atau pengantar. Gerlach \& Ely (dalam Aryad, 2011: 3) mengatakan bahwa media apabila dipahami secara garis besar adalah manusia, materi atau kejadian yang membangun kondisi yang membuat siswa mampu memperoleh pengetahuan, keterampian, atau sikap. Media secara harfiah berarti perantara atau pengantar pesan dari pengirim pesan ke penerima pesan (Arif S, Sadiman dkk 2012:6) . 


\section{8 | Arlianti}

Media audio visual merupakan peralatan suara dan gambar dalam satu unit seperti filem bersuara,televisi dan vidio. Namun, ada pengelompokan lain dari media audio visual yaitu peralatan visual seperti slidedan OHP yang diberi unsur suara dari rekaman kaset yang di manfaatkan secarabersamaan dalam satu waktu atau satu proses pembelajaran (Munadi 2010). Penampilan video yang dapat diulang sesuai dengan keinginan, membuat para siwa termotivasi untuk engamati dan menganaisis fenomena dalam kehidupan sehari-hari (Ika Risqi Citra Rima Vera, 2011).

Adapun jenis-jenis audio visual : 1) Laptop merupakan kebutuhan dasar bagi masyarakat, baik untuk pendidikan maupun untuk aktivitas bisnis. Namun, memilih laptop atau notebook yang tepat sesuai kebutuhan konsumen, spesifikasi laptop dan harga yang tepat bukanlah hal yang mudah (Suhendra Sunarsa 2016 : 5), 2) LCD proyektor merupakan salah satu media elektronik yang dapat digunakan oleh guru dalam proses belajar mengajar. LCD proyektor juga dapatmembantu guru untuk lebih mudah dalam mengajar dan pelajar lebih mudah dalam menerima pembelajaran. Selain jenis-jenis audio visual media ini juga juga mempunyai fungsi.

Fungsi media merupakan salah satu ide yang sangat tepat dalam menyiasati kejenuhan peserta didik karena pembelajaran dengan menggunakan media dirasa cukup efektif dan dapat menggairahkan semangat mereka dalam mengikuti jalannya proses belajar mengajar.

Hasil belajar dapat diartikan sebagai suatu tindakan atau suatu proses untuk menetukan nilai keberhasilan belajar seseorang setelah ia mengalami proses belajar selama satu priode tertentu (Wayan Nurkancana dan Sunartana. 2010: 11) Menurut pengertian secara psikologis belajar merupakan suatu proses perubahan yaitu perubahan tingkah laku sebagai hasil dari interaksi dengan lingkungannya dalam memenuhi kebutuhan hidupnya (Slameto. 2015:2). Hasil belajar dapat berupa pengetahuan (kongnitif), tingkah laku atau sikap (afektif), dan keterampilan (psikomotor), yang diperoleh peserta didik dalam proses pembelajaran. Dapat pula dikaitakan bahwa hasil belajar merupakan perolehan seseorang dari suatu perbuatan belajar, atau hasil belajar merupakan kecakapan nyata yang dicapai peserta didik dalam waktu tertentu. Hasil belajar yang utama adalah pola tingkah laku yang bulat yang diperoleh setiap peserta didik setelah proses belajar. Penelitian ini bertujuan untuk mengatahui penggunaan media audio visual dapat meningkatkan hasil belajar IPA di kelas III SDN 50 Bulu' Datu. 


\section{METODE}

Penelitian ini adalah penelitian tindakan kelas (PTK) dengan jenis data kualitatif dan kuantitaf. Pendekatan kuantitatif adalah pendekatan yang berupa angka-angka yang kemudian dianalisis dengan menggunakan statistik sedangkan pendekatan kualitatif adalah pendekatan yang tidak berupa angka. Penelitian ini menggunakan PTK yang bermaksud menggambarkan Peningkatan Hasil Belajar Peserta didik Dengan Menggunakan Media audio visual. Sesuai dengan jenis penelitian yang digunakan, maka penulis menggunakan model penelitian tindakan dari Kurt Lewin, hal ini dikarenakan model Kurt Lewin sesuai dengan proses penelitian yaitu perencanaa, tindakan, observasi, dan refleksi. Adapun lokasi penelitian ini dilakanakan di kelas III SDN 50 Bulu'Datu. Subjek dalam penelitian ini adalah seluruh peserta didik kelas III SDN 50 Bulu'Datu yang berjumlah 23 peserta didik, untuk mengumpulkan data dalam penelitian ini dilakukan dengan observasi, tes, dokumentasi.

\section{HASIL PENELITIAN}

Judulnya disesuaikan dengan redaksi/deskripsi rumusan masalah yang dimaksud. Bagian ini berisi hasil penelitian dan pembahasan terkait dengan rumusan masalah pertama.. Pada hasil penelitian terlebih dahulu paparkan hasil penelitian yang telah diperoleh tanpa menyertakan deskripsi hasil pemikiran penulis atau tinjauan pustaka. Pada bagian pembahasan berisi tentang penjelasan hasil penelitian dikaitkan dengan rumusan masalah dalam penelitian, interpretasi hasil penelitian, serta membandingkan atau mengaitkan hasil penelitian dengan teori yang dirujuk.

Penggunaan media audio visual dapat meningkatkan hasil belajar peserta didik. Dalam proses pembelajaran pertama guru memberikan materi kepada peserta didik tanpa menggunakan media, setelah menjelaskan materi guru mengevaluasi peserta didik sesuai dengan materi yang telah dijelaskan dalam proses pembelajaran kemudian, guru memberikan tugas kepada peserta didik untuk memperoleh hasil belajar pada siklus I.

Setelah penerapan siklus I maka guru dapat melihat peningkatan yang dialami oleh peserta didik. Dengan adanya proses pembelajaran yang berlangsung pada siklus I sehingga guru dapat menilai sejauh mana pemahaman siswa tentang materi yang disampaikan oleh guru karena media yang digunakan kurang menarik perhatian siswa dalam proses pembelajaran. Sehingga guru diharapkan agar lebih kreatif dalam proses pembelajaran.

Penggunaan media pembelajaran menyebabkan peserta didik lebih mudah dalam memahami materi yang diajarkan oleh guru namun, sebelum 


\section{0 | Arlianti}

menggunakan media audio visual peserta didik yang kurang bersemangat dalam mengikuti kegiatan pembelajaran seorang guru memberikan motivasi dalam pembelajaran sehingga peserta didik memiliki motivasi dalam mengikuti proses pembelajaran dan proses pembelajaran yang dilakukan pada siklus II dapat meningkat setelah diterapkannya media audio visual karena dengan penerapan audio vosual ini proses pembelajaran yang dilakukan di kelas sangat berpengaruh dengan peningkatan peserta didik dalam mengikuti proses pembelajaran. Sehingga dengan adanya bantuan audio visual guru dapat melihat peningkatan yang dialami oleh peserta didik.

\section{Deskripsi Siklus I}

Siklus I dilakasanakan selama 3 kali pertemuan, dengan 2 kali tatap muka dan 1 kali evaluasi dipertemuan akhir siklus. Berdasarkan prosedur penelitian tindakan kelas, ada beberapa langkah-langkah pada siklus I yang harus dilakukan yaitu Sebagai berikut:

\section{a. Perencanaan}

Guru kelas III (peneliti) menyiapkan Rencana Pelaksanaan Pembelajaran (RPP) yang dilengkapi dengan soal, istrumen-instrumen lainnya dan menyiapkan media audio visual. Selanjutnya menyiapkan lembar observasi yang terdiri dari proses pembelajaran guru dan aktivitas peserta didik dalam proses pembelajaran.

Setelah itu, peneliti mengadakan tes dan melakukan diskusi dengan guru tentang rencana pembelajaran yang telah disiapkan serta penjelasan cara pengisian lembar observasi.

b. Pelaksanaan Tindakan

Tahap ini, kegiatan pembelajaran dilaksanakan sesuai dengan rencana pelaksanaan pembelajaran yang telah dipersiapkan sebelumnya. Kegiatan pembelajaran diawali dengan membaca do'a sebelum memulai kegiatan proses belajar mengajar.

1) Guru melakukan langkah pembelajaran sesuai dengan skenario pembelajaran (rencana pembelajaran terlampir).

2) Peserta didik mengikuti kegiatan pembelajaran dan melaksanakan kegiatan sesuai dengan skenario kegiatan belajar mengajar.

3) Pengamat melakukan pengamatan sesuai dengan instrument pengamatan tentang aspek-aspek proses pembelajaran yang dilakukan guru dan aktivitas peserta didik dalam proses pembelajaran.

Berdasarkan tabel hasil evaluasi siklus I sehinnga nilai rata-rata hasil belajar peserta didik kelas III SDN 50 Bulu' Datu Kota Palopo diperoleh dengan rumus rata-rata: $\frac{1700}{23}=73$ jadi nilai rata-rata peserta didik dengan menggunakan media audio visual dalam pelajaran IPA diatas menunjukkan bahwa dari 23 peserta didik yang mengikuti tes evaluasi pada siklus I peserta 
didik yang mendapat nilai $\geq 70$ sebanyak 17 orang dan yang men dapat nilai dibawah KKM sebanyak 6 orang.

Apabila nilai hasil belajar peserta didik pada siklus I dikelompokkan dalam lima kategori maka hasil belajar peserta didik dipaparkan sebagai berikut:

Tabel pengkategorian siklus I

\begin{tabular}{|c|c|c|c|c|}
\hline No. & Nilai Angka & Kategori & Frekuensi & Persentase \\
\hline 1. & $80-100$ & Sangat baik & 4 & $17 \%$ \\
\hline 2. & $70-79$ & Baik & 14 & $60 \%$ \\
\hline 3. & $60-69$ & Cukup & 0 & $0 \%$ \\
\hline 4. & $50-59$ & Kurang & 5 & $22 \%$ \\
\hline 5. & $0-49$ & Gagal & 0 & $0 \%$ \\
\hline \multicolumn{3}{|c|}{ Jumlah } & 23 & $100 \%$ \\
\hline
\end{tabular}

Berdasarkan tabel diatas dapat diketahui bahwa 23 peserta didik yang mengikuti tes pada siklus I ternyata 4 peserta didik yang mendapat kategori sangat baik, 0 peserta didik mendapat nilai termasuk kategori cukup, 14 peserta didik mendapat nilai termasuk kategori baik, 5 peserta didik mendapat nilai kurang dan 0 gagal.

c. Observasi

Observasi yang dilakukan peniliti untuk mengetahui proses pembelajaran yang dilakukan dan aktivitas peserta didik dengan menggunakan lembar observasi yang telah disediakan oleh peneliti dan yang menjadi sasaran observasi peneliti yaitu aspek kognitif, afektif, dan psikomotorik. Data hasil penelitian baik kognitif (tertulis) maupun afektif dan psikomotorik (pengamatan) dilakukan untuk peserta didik, dan indikator aspek proses pembelajaran yang dilakukan guru dalam proses pembelajaran sesuai dengan instrumen pengamatan. Apsek-aspek proses pembelajaran yang dilakukan guru meliputi perencanaan, kegiatan utama, dan pemantapan.

d. Refleksi 


\section{2 | Arlianti}

Tahap selanjutnya adalah mengadakan refleksi yaitu membahas dan mengevaluasi proses pembelajaran yang baru saja dilaksanakan. Refleksi bertujuan agar kekurangan atau kendala pada siklus I dapat diketahui.

\section{Deskripsi Siklus II}

Siklus II dilaksanakan selama 3 kali pertemuan, dengan 2 kali tatap muka dan 1 kali evaluasi dipertemuan akhir siklus. Kegiatan pada siklus II ini adalah mengulang kembali kegiatan-kegiatan yang dilaksanakan pada siklus I dengan melakukan perbaikan-perbaikan yang masih dianggap kurang pada siklus I.

a. Perencanaan

Perencanaan pembelajaran yang dilaksanakan pada siklus II adalah sebagai berikut:

1) Menetapkan tujuan pembelajaran yang ingin dicapai

2) Mempersiapkan Rencana Peleksanaan Pembelajaran (RPP)

3) Mempersiapkan instrumen pengamatan (observasi) aktivitas guru dan siswa dalam kegiatan proses pembelajaran

4) Mempersiapkan media yang akan digunakan dalam proses pembelajaran

b. Pelaksanaan Tindakan

Guru melakukan langkah pembelajaran sesuai dengan RPP dengan berupaya memperbaiki kelemahan-kelemahan dalam proses pembelajaran yang dilakukan pada siklus I.

Berdasarkan tabel hasil evaluasi siklus II nilai rata-rata hasil belajar peserta didik SDN 50 Bulu' Datu Kota Palopo diperoleh dengan rumus ratarata $\frac{2200}{23}=95$ jadi nilai rata-rata peserta didik dengan menggunakan media audio visual dalam pembelajaran IPA pokok diatas menunjukkan bahwa dari 23 peserta didik yang mengikuti tes evaluasi pada siklus II peserta didik yang mendapat nilai $\geq 70$ sebanyak 23 orang dan tidak ada yang mendapat di bawah nilai KKM.

Apa bila hasil belajar peserta didik pada siklus II dikelompokkan dalam lima kategori maka hasil belajar peserta didik dipaparkan sebagai berikut:

Tabel pengkategorian siklus II 


\begin{tabular}{|c|c|c|c|c|}
\hline No. & $\begin{array}{c}\text { Nilai } \\
\text { Angka }\end{array}$ & Kategori & Frekuensi & Persentase \\
\hline 1. & $80-100$ & Sangat baik & 23 & $100 \%$ \\
\hline 2. & $70-79$ & Baik & 0 & $\%$ \\
\hline 3. & $60-69$ & Cukup & 0 & $\%$ \\
\hline 4. & $50-59$ & Kurang & 0 & $\%$ \\
\hline 5. & $0-49$ & Gagal & 0 & $\%$ \\
\hline \multicolumn{3}{|c|}{ Jumlah } & 23 & $100 \%$ \\
\hline
\end{tabular}

Berdasarkan tabel diatas terlihat bahwa persentase hasil belajar peserta didik setelah diterapkan media audio visual pada siklus II tidak ada peserta didik yang berada pada kategori gagal, tidak ada peserta didik yang berada pada kategori kurang, tidak ada peserta didik yang berada pada kategori cukup, tidak ada peserta didik yang berada pada kategori baik, dan peserta didik yang berada pada kategori sangat baik sebanyak 23 o rang.

Hasil belajar peserta didik pada siklus I dapat dilihat pada diagram berikut:

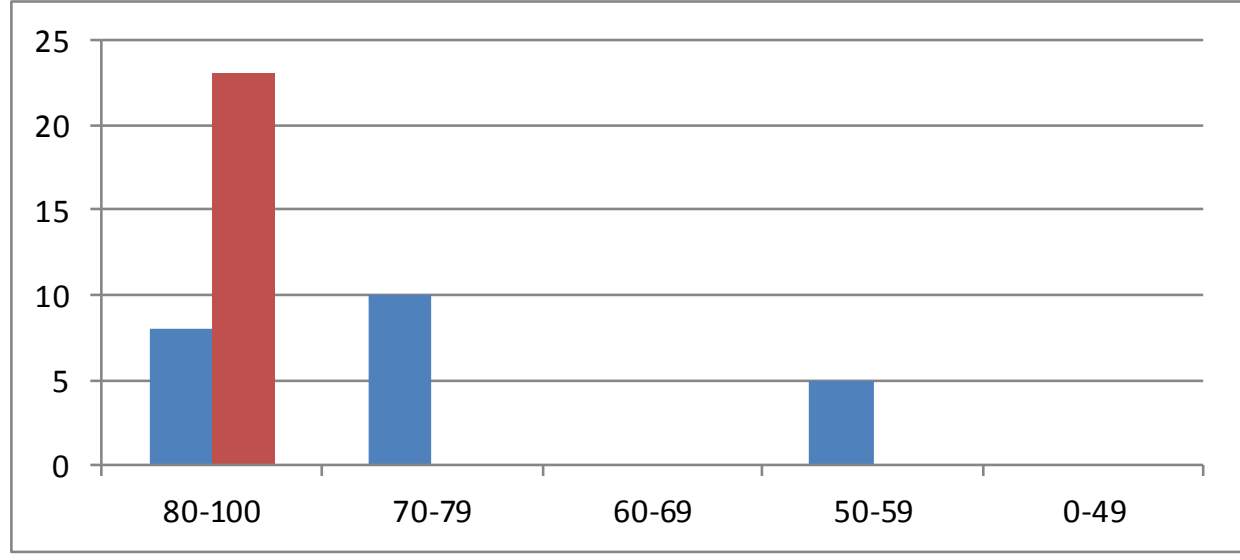

Gambar 2 Diagram Hasil Belajar Peserta Didik Siklus I

Berdasarkan diagram di atas dapat dilihat bahwa hasil belajar peserta didik kelas III SDN 50 Bulu'Datu terdapat 17 peserta didik yang memenuhi standar, namun masih ada 6 peserta didik yang belum mencapiai nilai KKM maka dari itu perlu dilanjutkan ke siklus II.

Berdasarkan hasil evaluasi pada siklus II menunjukkan bahwa hasil belajar peserta didik kelas III SD 50 Bulu' Datu telah mencapai nilai rata-rata 23 dengan persentase ketuntasan 100\%. Berdasarkan nilai ketuntasan minimum pada mata pelajaran IPA dengan standar KKM 70 sehingga peneliti mengakhiri tindakan ini sampai siklus II.

c. Observasi

Peneliti melakukan observasi seperti yang dilakukan pada siklus II. Tahap observasi pada siklus I tercatat sikap yang terjadi pada setiap peserta didik terhadap pelajaran IPA. Sikap peserta didik tersebut diperoleh dari 


\section{4 | Arlianti}

lembar observasi pada setiap pertemuan yang dicatat pada setiap siklus, lembar observasi tersebut digunakan untuk mengetahui perubahan cara mengajar guru dan sikap peserta didik pada setiap pertemuan selama proses belajar mengajar berlangsung.

d.Refleksi

Berdasarkan hasil yang diperoleh di atas masih terdapat kekurangan yang harus diperbaiki pada pelaksaan pada tindakan siklus I dan perbaiakan yang dilakukan pada siklus selanjutnya. Pelaksanaan pembelajaran dengan menggunakan media audio visual telah berjalan sesuai dengan rancangan yang telah disusun sebelumnya. Setelah itu, setelah melihat hasil observasi pembelajaran di dalam kelas dan hasil observasi belajar peserta didik, diketahui bahwa penggunaan media audio visual telah meningkatkan hasil belajar peserta didik dari siklus I ke siklus II.

Berdasarkan presentase ketuntasan hasil belajar peserta didik kelas III SD 50 Bulu'Datu palopo setelah menggunakan media pembelajaran yaitu media audio visual pada pembelajaran IPA, dapat dilihat bahwa banyaknya peserta didik yang tuntas pada siklus I sebanyak 15 peserta didik tau $65 \%$ dan banyaknya peserta didik yang tidak tuntas sebanyak 8 peserta didik atau 35\%, sedangkan peserta didik yang tuntas pada siklus II sebanyak 23 sekitar 100\%. Adapun hasil evaluasi pada prasiklus dengan nilai rata-rata mencapai 63, siklus I dengan nilai rata-rata 73 , sedangngkan pada siklus II nilai rata-rata mencapai 95.

Media pembelajaran sangatmembantu dalam peningkatan hasil belajar peserta didik. Penggunaan alat media peraga menjadi salah satu dari media pendidikan yang membantu proses belajar mengajar sehingga proses komunikasi dapat berhasil dengan baik dan efektif.

\section{PEMBAHASAN PENELITIAN}

Pada bagian ini, alur penjelasannya hampir sama dengan pembahasan rumusan masalah pertama.

Dalam pembahasan ini diuraikan hasil penelitian mengenai peningkatan hasil belajar IPA melalui media audio visual. Berdasarkan penelitian, penggunaan media audio visual ternyata dapat meningkatkan hasil belajar IPA pada peserta didik kelas III SD 50 Bulu' Datu Palopo. Hal ini dikarenakan pembelajaran menggunakan media audio visual dalam proses pembelajaran dapat menarik perhatian peserta didik sehingga membantu meningkatkan pemahaman peserta didik terhadap pelajaran yang disampaikan guru.

Dalam penggunaan media audio visual, guru dapat menerapkan berbagai metode dan model-model pembelajaran yang menarik dalam penyampaian materi sehingga peserta didik tidak merasa jenuh dalam belajar. Guru bisa menggunakan media dan metode lain yang relevan dengan materi pelajaran. 
Hal ini sesuai dengan pendapat Sutirman media pembelajaran dapat diartikan sebagai alat-alat gratis, photografis,atau elektronis, yang dapat digunakan untuk menangkap, memproses, dan menyusun kembali informasi visual atau verbal (Sutirman, 2013: 15).

Media pembelajaran merupakan sarana komunikasi dalam bentuk cetak maupun pandang dan dengan termaksud perangkat keras. Guru dalam menyampaikan materi pelajaran hendaknya menggunakan media pendidikan yang menarik dan membantu pemahaman siswa (Budiyanto 2009). Dalam hal ini, guru dapat menggunakan media audio visual sebagai salah satu metode yang dapat menarik perhatian siswa karena dengan menggunakan media audio visual para peserta didik tidak serta merta hanya menerima pelajaran saja akan tetapi imajinasi peserta didik juga dapat terlatih melalui media audio visual tersebut.

Penggunaan media alat peraga merupkan salah satu contoh media pendidikan dalam membantu proses belajar mengajar agar proses pembelajaran dapat berhasil sesuai yang diharapkan, hal tersebut berkenanaan dengan pendapat Fitrima bahwa media memiliki tugas sebagai guru dan menajadi sumber belajar bagi peserta didiknya, dengan demikian media memiliki peran utama dalm keberhasilan pendidikan (fitrima santri. 2016:121).

Belajar menurut kaum behavioris menekankan pada perubahan perilaku yang dapat diamati dari hasil hubungan timbal balik antara pendidik sebagai pemberi stimulus dan peserta didik sebagai perespon tindakan stimulus yang diberikan (Muhammad Yaumi, 2013:29), telah dijelaskan pada pembahasan sebelumnya bahwasanya pembelajaran itu bisa dikatakan berhasil ketika para peserta didik mengalami kemajuan baik itu dalam hal pengetahuan, keterampilan, maupun sikap.

Berdasarkan presentase ketuntasan hasil belajar peserta didik kelas III SD 50 Bulu'Datu palopo setelah menggunakan media pembelajaran yaitu media audio visual pada pembelajaran IPA, dapat dilihat bahwa banyaknya peserta didik yang tuntas pada siklus I sebanyak 15 peserta didik tau $65 \%$ dan banyaknya peserta didik yang tidak tuntas sebanyak 8 peserta didik atau 35\%, sedangkan peserta didik yang tuntas pada siklus II sebanyak 23 sekitar 100\%. Adapun hasil evaluasi pada prasiklus dengan nilai rata-rata mencapai 63, siklus I dengan nilai rata-rata 73 , sedangngkan pada siklus II nilai rata-rata mencapai 95.

Media pembelajaran sangat membantu dalam peningkatan hasil belajar peserta didik. Penggunaan alat media peraga menjadi salah satu dari media pendidikan yang membantu proses belajar mengajar sehingga proses komunikasi dapat berhasil dengan baik dan efektif. 


\section{PENUTUP}

Penggunaan media Audio Visual dapat meningkatkann hasil belajar peserta didik kelas III SDN 50 Bulu' Datu palopo pada mata pelajaran IPA. Hal ini dapat terlihat dari perolehan skor rata-rata pada siklus I yaitu 73 sedangkan perolehan score hasil belajar peserta didik pada siklus II yaitu 95 dapat dikategorikan hasil belajar peserta didik meningkat. Melalui media Audio Visual peserta didik terlihat aktif dalam proses pembelajaran.

\section{DAFTAR PUSTAKA}

Azhar Arsyad. 2014. Media pembelajaran,Jakarta: Rajawali Pers.

Mayasari Diana Erna, 2015. Peggunaan Media Audio Visual Video untuk Meningkatkan Hasil Belajar Siswa pada Mata Pelajaran Sosiologi kelas X2 SMAN Kebakramat

Hisbullah \& Nurhayati Selvi. 2018. Pembelajaran Ilmu Pengetahuan Alam di Sekolah Dasar Makassar : Aksara Timur.

Nurkancana Wayan \& Sunartana. 2010. Evaluasi Hasil Belajar Surabaya : Usaha Nasional.

Rustan, E. (2001). Budaya Leluhur dalam Memperkukuh Tatanan Masyarakat di Era Globalisasi. In Seminar Internasional Pemertahanan Identitas Masyarakat Multikultural di Era Globalisasi (pp. 79-86). Surabaya.

Rustan, E., Hanifah, N., \& Kanro, B. (2018). De-radicalization in the Implementation of Islamic Education Curriculum in SMA Masamba South Sulawesi. Dinamika Ilmu, 18(2), 271-283. https://doi.org//10.21093/di.v18i2.1338

Sadiman Arif S. dkk. 2012. Media Pendidikan,Depok :Rajawali Pres.

Slameto. 2015. Belajar dan Faktor-Faktor yang Mempengaruhinya Jakarta : Rineka Cipta.

Sugiyono. 2012. Metode Penelitian Kuantitatif Kualitatif dan R\&D, Bandung: Alfabeta.

Susanto Ahamad. 2015. Teori Belajar dan Pembelajaran. Jakarta, Kencana.

Sutirman. 2013. Media dan Model-Model Pembelajaran Inovatif. Yogyakarta, Graha Ilmu.

Syamsu. 2015. Strategi PembelajaranMakassar : Aksara Timur.

H.M. Musfiqon. 2012. Metodologi Penelitian pendidikan, Jakarta PT. Prestasi pustakarya

Anas Sudijono, 2010 Pengantar Statistik Pendidikan, Jakarta : PT Raja GrapindoPersada 
Rusman. 2014. Model-Model Pembelajaran: Mengembangkan Profesionalisme Guru, Jakarta: Rajawali Pers.Slameto. 2013. Belajar dan Faktor-faktor yang Mempengaruhinya. Jakarta: Rineka Cipta.

Sujana, Atep. (2014). Pendidikan IPA teori dan praktek.sumedang.risqi pres

Sri anita. Penggunaan media audio visual pada mata pelajaran ilmu pengetahuan alam sekolah menegah pertama negri 1 pacitan, jurnal teknologi pendidikan dan pembelajaran, vol 2, no 22014

Trianto, 2010, Model Pembelajaran Terpadu, Jakarta: PT Bumi Aksara

Munadi Y, 2010, media pembelajaran. Jakarta: gaung press

Yaumi Muhammad, 2013. Prinsip-PrinsipDesain Pembelajaran, Cet. II, Jakarta, Kencana.

Vera, Ika Risqi Citra,2014. Pengaruh Media Audio Visual terhadap Hasil Belajar Siswa kelas XI pada Konsep Klastisitas, vol. 3, no. 3.

Wardani, dian, dkk., "origami terhadap kecerdasan spasial matematika siswa," jurnal pendidikan: teori, pnelitian, dan pengembangan, vol. 1 no 5, mei 2016 
28 | Arlianti

---Halaman sengaja dikosongkan--- 